\title{
FINASTERIDE-ASSOCIATED MALE INFERTILITY
}

\author{
Sidney Glina, Paulo Augusto Neves, Ricardo Saade, Nelson Rodrigues Netto Jr., \\ Jonathas Borges Soares and Andrea Giannotti Galuppo
}

GLINA S et al. Finasteride-associated male infertility. Rev. Hosp. Clín. Fac. Med. S. Paulo 59(4):203-205, 2004.

Finasteride is a potent and specific inhibitor of the $5 \alpha$-reductase enzyme in men. Clinical studies have shown that finasteride $1 \mathrm{mg}$ /day is effective for promoting hair growth in men with male pattern hair loss. However, there is a concern about the use of finasteride, especially in young fertile patients, because of its action on testosterone metabolism. This paper describes 3 cases of young patients who had very poor seminal quality during finasteride treatment (1 mg/day), and their seminal quality greatly improved after cessation of finasteride treatment. Two of them presented with a left varicocele and the other was obese. We hypothesize that finasteride may not dramatically change the spermatogenesis process in healthy men, but in patients with conditions related to infertility, an amplification of the negative influence of finasteride could occur. Future studies should be done to clarify the extent of the effect of finasteride in patients fertility problems.

KEY WORDS: Finasteride. Fertility. Spermatogenesis. Sperm. Seminal parameters.

Finasteride is a potent and specific inhibitor of the $5 \alpha$-reductase enzyme. ${ }^{1}$ It inhibits the conversion of testosterone to dihydrotestosterone (DHT). ${ }^{2}$ Dihydrotestosterone is the most potent androgen, and its level directly affects prostate development.

It is known that the use of $5 \alpha$-reductase enzyme inhibitors like finasteride, when administered at $5 \mathrm{mg} /$ day, reduce the prostatic size around $20 \%$ to $30 \% .^{3}$ Finasteride has been used for the treatment of benign prostate hyperplasia. Clinical studies have shown that finasteride $1 \mathrm{mg} /$ day is also effective in promoting hair growth in men with male pattern hair loss. ${ }^{4}$

There has been a concern regarding the use of finasteride, especially in young patients, because of its action on testosterone metabolism. Overstreet et al. (1999) demonstrated in a prospective clinical trial that treatment with finasteride $1 \mathrm{mg} /$ day does not affect spermatogenesis or the spermatozoa production in young healthy men. ${ }^{1}$ However, Kinniburg et al. (2001) showed that the use of finasteride promotes a significant reduction of the serum level of DHT, decrease of the plasma seminal volume, and the suppression of gonadotropin secretion, resulting in impairment of spermatogenesis. $^{2}$ O'Donnel et al. (1999) showed in an animal model that the use of finasteride promoted partial inhibition of spermatogenesis. ${ }^{2}$ A Medline review searching with the key words finasteride and fertility produced 3 papers related to the positive influence of finasteride on the fertility, but none of them were performed with humans.

From the Human Reproduction Unit, Albert Einstein Jewich Hospital - São Paulo/SP, Brazil.

E-mail: glinas@terra.com.br Received for publication on January 07, 2004.
Cukierski et al. (1991) and Wise et al. (1991) showed that in rats the administration of $80 \mathrm{mg} / \mathrm{kg} /$ day of finasteride decreased fertility. ${ }^{5,6}$ According to Iguer-Ouada et al. (1997), finasteride (1 $\mathrm{mg} / \mathrm{kg}$ ) promoted an increase in sperm concentration and decrease in volume of prostatic secretion in male beagle dogs. ${ }^{7}$ The effects on the fertility of a long period of finasteride treatment are not completely defined.

The aim of this study was describe 3 cases of young male patients who consulted for infertility and showed severe decrease of spermatogenesis during finasteride treatment ( $1 \mathrm{mg} /$ day $)$.

\section{CASE REPORT}

\section{Patient 1}

A male patient, aged 31 years, presented for fertility evaluation. He and his 
wife had been trying to achieve pregnancy for 10 months. He had a varicocele diagnosed 10 years earlier, and at that time, he had not been surgically treated because he had had a normal seminal analysis. He had been on finasteride $1 \mathrm{mg}$ /day for 2 years because of hair loss. His physical exam showed a normal testis and a moderate left varicocele. His first seminal analysis showed 8.2 million sperm $/ \mathrm{mL}$ with $70 \%$ motility, and $7 \%$ normally shaped spermatozoa, according the Kruger criteria. ${ }^{8}$ The second analysis showed 7 million sperm/ $\mathrm{mL}$, with $57 \%$ motility and $10 \%$ of normal shape. Before a varicocele repair, the patient was asked to interrupt finasteride for 4 months. After that period, a new seminal analysis showed a total concentration of 50 million spermatozoa, with $70 \%$ motility and $19 \%$ of normal shape. ${ }^{8}$

\section{Patient 2}

A male patient, aged 33 years, was referred for fertility evaluation. He and his wife had been trying to achieve a pregnancy for 6 months. He had been on finasteride $1 \mathrm{mg}$ /day for 1 year because of hair loss. At the physical exam, the testes were normal, but there were small cysts in the head of the epididymis bilaterally and a moderate-sized left varicocele. His seminal analysis showed a total sperm concentration of 15 million spermatozoa/ml with $20 \%$ motility and $17 \%$ normally shaped spermatozoa $/ \mathrm{ml}^{8}$ Finasteride was interrupted for 3 months, and a new seminal analysis showed a total concentration of 43 million spermatozoa/ml with $42 \%$ motility and $15 \%$ of normal shape. ${ }^{8}$

\section{Patient 3}

An obese male patient, aged 32 years, was referred for infertility evaluation. The couple had been trying to achieve pregnancy for 6 months. He had been on finasteride $1 \mathrm{mg}$ /day for more than 1 year. There were no abnormalities in his physical exam. His first seminal analysis presented total concentration of 970,000 spermatozoa/ml with $30 \%$ motility and $16 \%$ normally shaped spermatozoa/ml. ${ }^{8}$ A second exam showed a total concentration of 360 thousand spermatozoa/ml with $20 \%$ motility and $15 \%$ of normal shape. Finasteride treatment was interrupted, and after 3 months a seminal analysis showed a total concentration of 10 million spermatozoa/ml with $60 \%$ motility and $22 \%$ of normal shape. ${ }^{8}$ Another seminal analysis was done 3 months later and showed total concentration of 7.2 million spermatozoa/ml with $50 \%$ motility and $22 \%$ of normal shape.

\section{DISCUSSION}

Finasteride has been used for the treatment of benign prostate hyperplasy and male pattern hair loss. Many young men in their fertile age have used this drug for long periods because of hair loss.

Finasteride inhibits $5 \alpha$-reductase, preventing the transformation of testosterone to dihydrotestosterone, which could cause a negative influence on the sperm production. O'Donnell et al. (1999) showed a negative impact of finasteride in rat spermatogenesis. ${ }^{9}$ However, Overstreet et al. (1999) reported that finasteride $1 \mathrm{mg} /$ day did not affect spermatogenesis, seminal production, sperm motility, or sperm morphology in young healthy men. ${ }^{1}$

The 3 patients reported on this paper showed abnormal sperm concentration and motility while using finasteride $1 \mathrm{mg} /$ day. Those alterations were completely reversed (patient 1 and 2) or improved (patient 3 ) 3 or 4 months after the interruption of finasteride treatment. The first patient had a history of having a normal seminal analysis 10 years before when he had been seen by a urologist to evaluate the need for a varicocele repair, which was not done at that time. In case 3 there was a dramatic improvement from less than 1 million sperm/ $\mathrm{mL}$ to 10 million sperm/mL 3 months after cessation of finasteride treatment. Although the improved sperm concentration was still abnormal, it permitted the couple to be treated with intrauterine insemination instead of with intracytoplasmic sperm injection.

It is interesting to stress that 2 patients had a varicocele and the third one was obese. We hypothesize that perhaps finasteride does not dramatically change the spermatogenesis process in healthy men as shown by Overstreet et al. (1999), but in patients with other problems contributing to infertility, the negative influence of finasteride noted by others might be amplified. Future studies should be done to clarify the extent of the effect of finasteride in patients with fertility problems.

\section{RESUMO}

GLINA S e col. Infertilidade masculina associada ao uso de finasterida.

Rev. Hosp. Clín. Fac. Med. S. Paulo 59 (4):203-205, 2004.
A finasterida é um potente e específico inibidor da enzima $5 \alpha$-redutase em homens. Estudos clínicos demonstraram que finasterida $1 \mathrm{mg} /$ dia diminui a progressão da queda e aumenta o crescimento do cabelo em homens que sofrem de queda de cabelo hereditária. Por sua influência no metabolismo dos andrógenos existe uma preocupação a respeito do seu uso, principalmente em 
pacientes em idade fértil. Neste trabalho são descritos 3 casos de pacientes jovens, que apresentaram piora do espermograma durante o uso continuado de finasterida $1 \mathrm{mg}$ revertida após a suspensão do mesmo. Dois deles tinham varicocele unilateral e o terceiro era obeso. Aparentemente o tratamento com finasterida promoveu alte- ração significativa na qualidade seminal. Pode-se especular que talvez a finasterida por si só não traga alteração para a espermatogênese como reportado por Overstreet et al. (1999), mas que em pacientes de risco com possíveis causas de infertilidade associadas, possa ocorrer a amplificação da influência deletéria da finasterida. Estudos futuros devem ser realizados para esclarecer a influência da finasterida nestes pacientes.

UNITERMOS: Finasterida. Fertilidade. Espermatogênese. Espermatozóide. Parâmetros seminais.

\section{REFERENCES}

1. Overstreet JW, Fuh VL, Gould J, Howards SS, Lieber MM, Hellstrom W, et al. Chronic treatment with finasteride daily does not affect spermatogenesis or semen production in young men. J Urol 1999;162:1295-300.

2. Kinniburg D, Anderson RA, Baird D. Suppression of spermatogenesis with desogestrel and testosterone pellets is not enhanced by addition of finasteride. J Androl 2001;22(1):88-95.

3. Steers WD. 5á-reductase activity in the prostate. Urol 2001;58(6suppl 1):17-24.

4. Van Neste D, Fuh V, Sanchez-Pedreno P, Lopez-Bran E, Wolff H, Whiting D, et al. Finasteride increases anagen hair in men with androgenetic alopecia. Br J Dermatol 2000;143:804-10.

5. Cukierski MA, Sina JL, Prahalada S, Wise LD, Antonello JM, Macdonald JS. Decreased fertility in male rats administered the 5 alpha-reductase inhibitor, finasteride, is due to deficits in copulatory plug formation. Reprod Toxicol 1991;5(4):353-62.
6. Wise LD, Minsker DH, Cukierski MA, Clark RL, Prahalada S, Antonello JM, MacDonald JS, Robertson RT. Reversible decreases of fertility in male Sprague-Dawley rats treated orally with finasteride, a 5 alpha-reductase inhibitor. Reprod Toxicol 1991;5(4):353-62.

7. Iguer-Ouada M, Verstegen JP. Effect of finasteride (Proscar MSD) on seminal composition, prostate function and fertility in male dogs. J. Reprod Fertil Suppl 1997;51:139-49.

8. Krüger TF, Acosta AA, Simmons KF, Swanson RJ, Matta JF, Oehninger S. Predictive value of abnormal sperm morphology in in vitro fertilization. Fertil Steril 1988;49:112-17.

9. O’Donnell L, Pratis K, Stanton PG, Robertson DM, McLachlan RI. Testosterone-dependent restoration of spermatogenesis in adult rats is impaired by $5 \alpha$-reductase inhibition. J Androl 1999; 20: 109-117. 